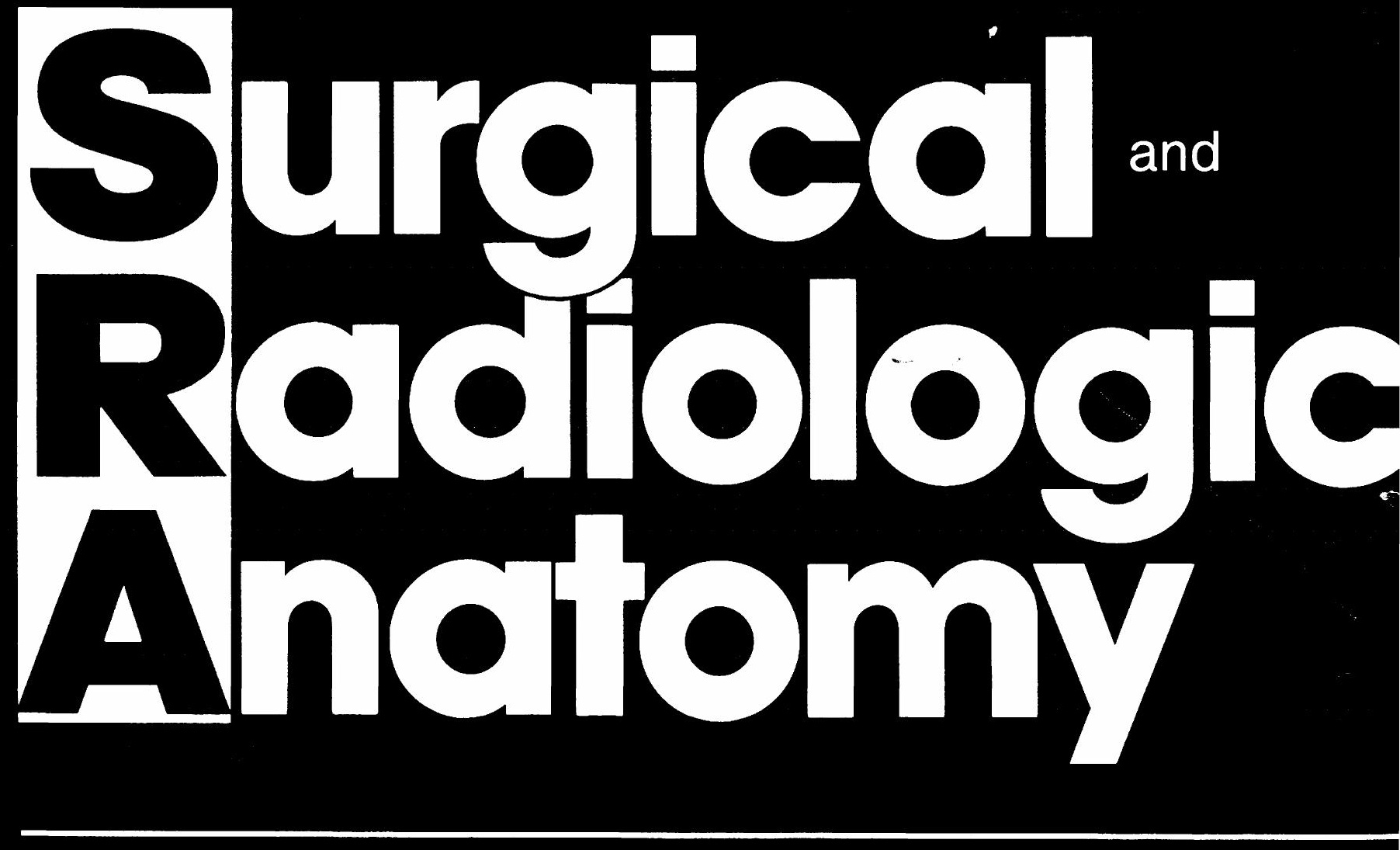




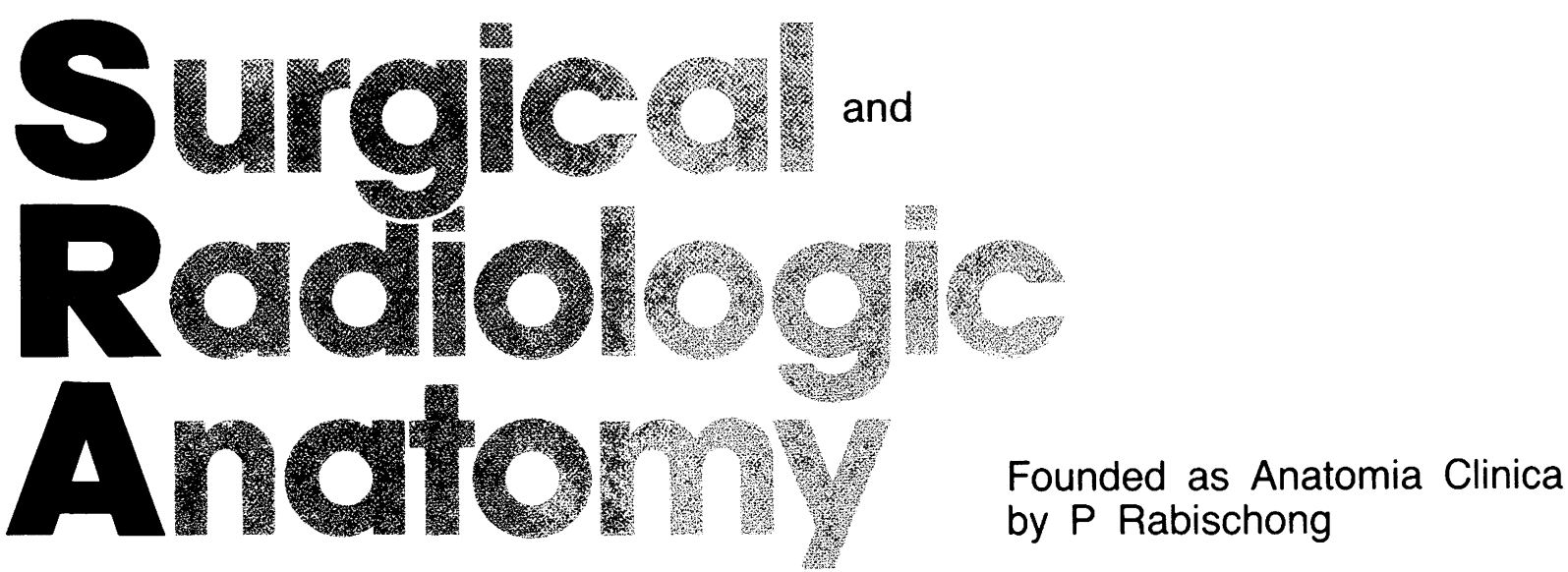

\section{Journal of Clinical Anatomy}

Anatomy is a morphological science which cannot fail to interest the clinician. The practical application of anatomical research to clinical problems necessitates special adaptation and selectivity in choosing from numerous international works. Although there is a tendency to believe that meaningful advances in anatomy are unlikely, constant revision is necessary. Surgical and Radiologic Anatomy, the first international journal of Clinical anatomy has been created in this spirit.

Its goal is to severe clinicians, regardless of speciality-physicians, surgeons, radiologists or other specialists-as an indispensable aid with which they can improve their knowledge of anatomy. Each issue includes: Original papers, review articles, articles on the anatomical bases of medical, surgical and radiological techniques, brief reviews of anatomical publications of clinical interest.

Particular attention is given to high quality illustrations, which are indispensable for a better understanding of anatomical problems.

Surgical and Radiologic Anatomy is a journal written by anatomists for clinicians with a special interest in anatomy.

\section{Copyright}

Submission of a manuscript implies: that the work described has not been published before (except in the form of an abstract or as part of a published lecture, review of thesis); that it is not under consideration for publication elsewhere that its publication has been approved by all coauthors, if any, as well as by the responsible authorities at the institute where the work has been carried out; that, if and when the manuscript is accepted for publication, the authors agree to automatic transfer of the copyright to the (publisher, society); and that the manuscript will not be published elsewhere in any language without the consent of the copyright holders.

All articles published in this journal are protected by copyright, which covers the exclusive rights to reproduce and distribute the article (e.g., as offprints), as well as all translation rights. No material published in this journal may be reproduced photographically or stored on microfilm, in electronic data bases, video disks, etc., whithout first obtaining written permission from the publisher.
The use of general descriptive names, trade names, trademarks, etc., in this publication, even if not specifically identified, does not imply that these names are not protected by the relevant laws and regulations.

While the advice and information of this journal is believed to be true and accurate at the date of its going to press, neither the authors, the editors, nor the publisher can accept any legal responsability for any errors or omissions that may be made. The published makes no warranty, express or implied, with respect to the material contained herein.

\section{Special regulations for photocopies in the USA.}

Photocopies may be made for personal or inhouse use beyond the limitations stipulated under Section 107 or 108 of U.S. Copyright Law provided a fee is paid. This fee is US $\$ 0.20$ per page, or a minimum of US $\$ 1.00$ if an article contains fewer than five pages. All fees should be paid to the Copyright Clearance Center, Inc., 21 Congress Street Salem MA 01970, USA stating the ISSN 0930-312X, the volume, and the first and last page numbers of each article copied. The copyright owner's consent does not include copying for general distribution, promotion, new works, or resale. In these cases, specific written permission must first be obtained from the publisher.

\section{Subscription information}

Volume 15 (4 issues) appears in 1993.

France and French-speaking countries.

Edition with complete French translation

Subscription rate; FF 1.850 .00 , including postage and handling. Orders should be addressed to:

\section{Dawson France/Service Diffusion}

Rue de la Prairie, BP 40

F-91121 Palaiseau Cedex

Tel. (1) 69090122

Telex 600394 F, FAX 1/64 548326

Membership of the European Association of Clinical Anatomy, the "Collège Médical Français des Professeurs d'Anatomie" and of the French Society of Radiology offers reduced subscription rates of the journal.

North America. Annual subscription rate: approx. US $\$ 388.00$ (single issue price: approx.

US $\$ 114.00$ ) including carriage charges. Subscriptions are entered with prepayment only.
Orders should be addressed to: Springer-Verlag New York Inc. Service Center Secaucus 44 Hartz Way

Secaucus, NJ 07094, USA

Tel. (201) 348-40 33, Telex 0023125994

Fax (201) 348-4505

All other countries. Orders subsricptions can either be placed via a bookdealer or sent directly to:

Springer-Verlag

Heidelberg Platz 3

D-14197 Berlin

Tel. (030) 80 07-0, Telex 01-83319

FAX (0)30/821 4091

Changes of address: Allow six weeks for all changes to become effective. All communications should include both old and new addresses (with Postal Codes) and should be accompanied by a mailing label from a recent issue.

Back volumes: Prices are available on request.

Microform: Microform editions are available from: University Microfilms International

300 N. Zeeb Road

Ann Arbor, MI 48106, USA

\section{Production}

Springer-Verlag France

J. York

26, rue des Carmes

F-75005 Paris

Tel. (331) 43261107

FAX (331) 43544908

\section{Advertissements}

Mlle Anne Auquier,

Springer-Verlag France

26 , rue des Carmes

F-75005 Paris

Tél. (331) 44411589

FAX (331) 43544908

Production and acquisition editor

Directrice de la publication : J Tovar

Imprimerie Soulisse et Cassegrain

Niort, France

D.L. 3073

(C) Springer-Verlag France

Printed in France

C.P. : 71753 


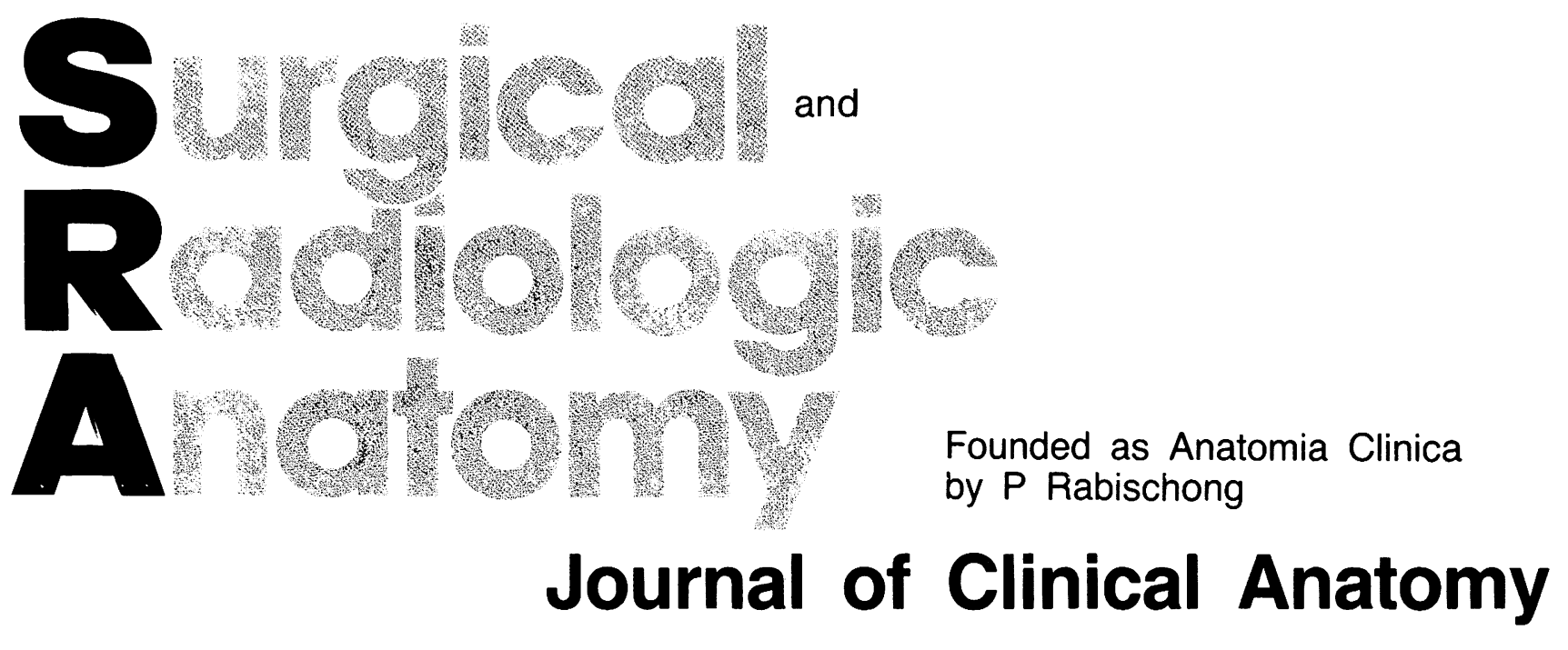

Editor-in-Chief JP Chevrel, Paris, France

Associate Editor H Ellis, Cambridge, United Kingdom

Honorary Editor J Pegington, London, United Kingdom

$\begin{array}{ll}\text { Managing } & \text { GT Ho } \\ \text { Editors } & \text { Chongquing, PR Chi } \\ & \text { T Naidich DI } \\ & \text { Miami, USA } \\ \text { Assistant } & \text { F Anderhuber } \\ \text { Editors } & \text { Graz, Austria } \\ & \text { C Fontaine } \\ & \text { Lille, France }\end{array}$

International

Advisory

Board

$\begin{array}{ll}\text { P Abrahams } & \text { SA Georgescu } \\ \text { London, UK } & \text { Bucharest, Rumania } \\ \text { G Bastide } & \text { G Godlewski } \\ \text { Toulouse, France } & \text { Nimes, France } \\ \text { J Best DI } & \text { A Gouazé } \\ \text { Edinburgh, UK } & \text { Tours, France } \\ \text { F Bonnel } & \text { RS Harris DI } \\ \text { Montpellier, France } & \text { St John's, Canada } \\ \text { B Brogdon DI } & \text { D Hartman DI } \\ \text { Mobile, USA } & \text { Washington, USA } \\ \text { M Caix } & \text { RE Heitzman DI } \\ \text { Limoges, France } & \text { Syracuse, USA } \\ \text { LJA DiDio } & \text { IM Holland DI } \\ \text { Toledo, USA } & \text { Nottingham, UK } \\ \text { C Faure } & \text { LG Kempe } \\ \text { Grenoble, France } & \text { Charleston, USA } \\ \text { W Firbas } & \text { B Kendall DI } \\ \text { Vienna, Austria } & \text { London, UK } \\ \text { JB Flament } & \text { C Kénési } \\ \text { Reims, France } & \text { Créteil, France } \\ \text { P Franchebois } & \text { J Kirklin DI } \\ \text { Montréal, Canada } & \text { Birmingham, UK }\end{array}$

S Nazarian
Marseille, France
R Putz
Munich, Germany
JP Francke DI
Lille, France
O Gagey
Paris, France

Bucharest, Rumania

G Godlewski

Nimes, France

A Gouaze

RS Harris DI

St John's, Canada

D Hartman DI

Washington, USA

RE Heitzman DI

LG Kempe

Charleston, USA

Créteil, France

Birmingham, UK

\author{
T Sato \\ Tokyo, Japan \\ $B$ Sénécail DI \\ Brest, France
}

R Pabst
Hannover, Germany
E Sassoon
London, UK

SZ Zhong

Guangzhou, PR China

J Koebke

Cologne, Germany

Y Kuru DI

Tokyo, Japan

K Lackner DI

Wurzburg, Germany

$J$ Lang

Wurzburg, Germany

$P$ Lasjaunias $D I$

Paris, France

$P$ Le Floch-Prigent

Paris, France

$R$ Louis

Marseille, France

DA McGrouther

London, UK

$\mathrm{H}$ Meire DI

London, UK

A Morin

Lyon, France

M Moscovici

Rio de Janeiro, Brazil
ME Müller

Bern, Switzerland

H Nahum DI

Paris, France

CV Penteado

Campinas, Brazil

W Platzer

Innsbruck, Austria

U Schumacher

Southampton, UK

E van der Zypen

Bern, Switzerland

G Vanneuville

Clermont-Ferrand, France

$M$ Viamonte $D I$

Miami Beach, USA

EA Zerhouni DI

Baltimore, USA

HZ Zhang

Wuhan, PR China

* DI Diagnostic Imaging 


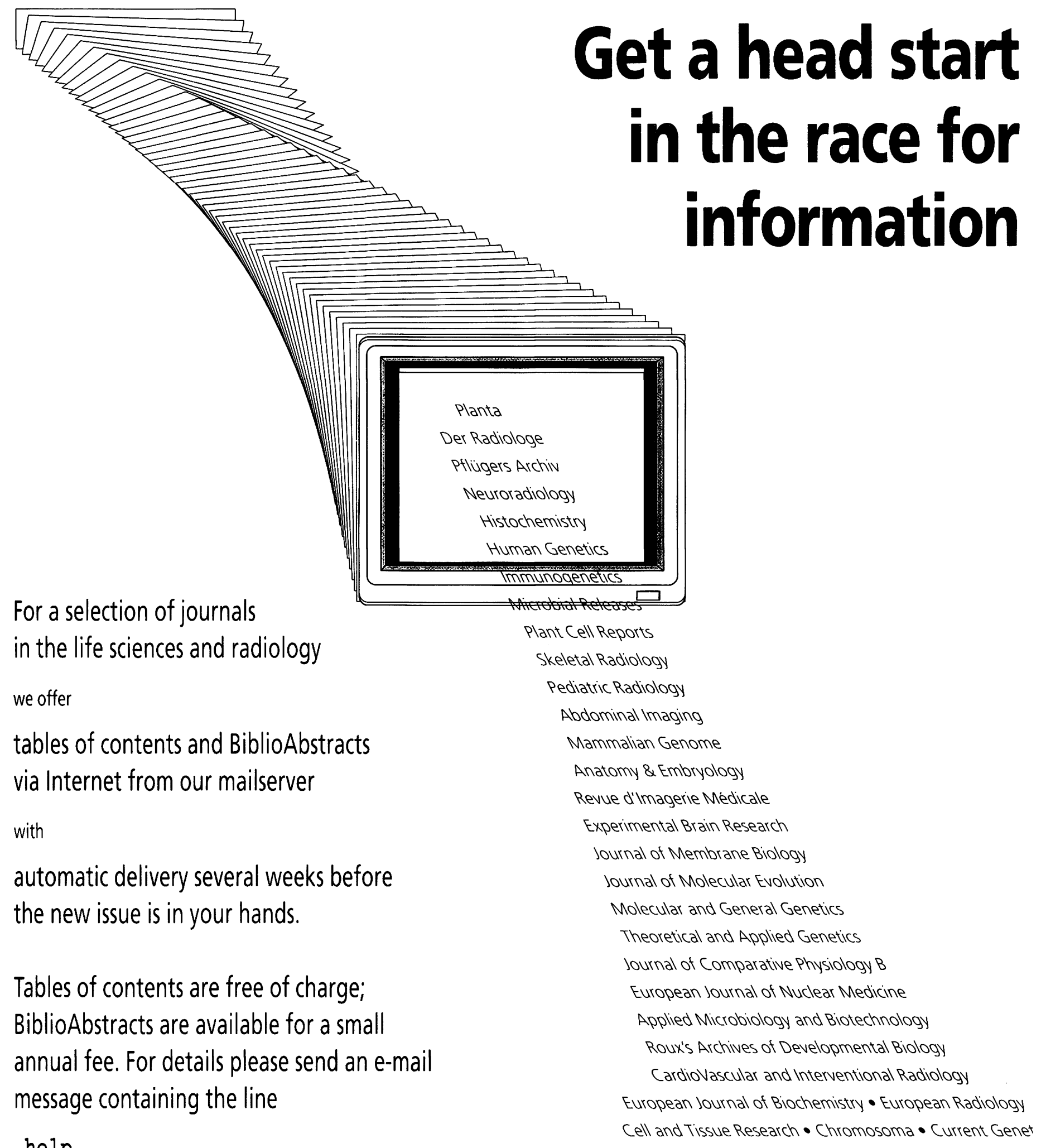

help

to our mailserver svjps@vax.ntp.springer.de

Please do not send regular e-mail to this address.

\section{Springer New Media Journals Preview Service}




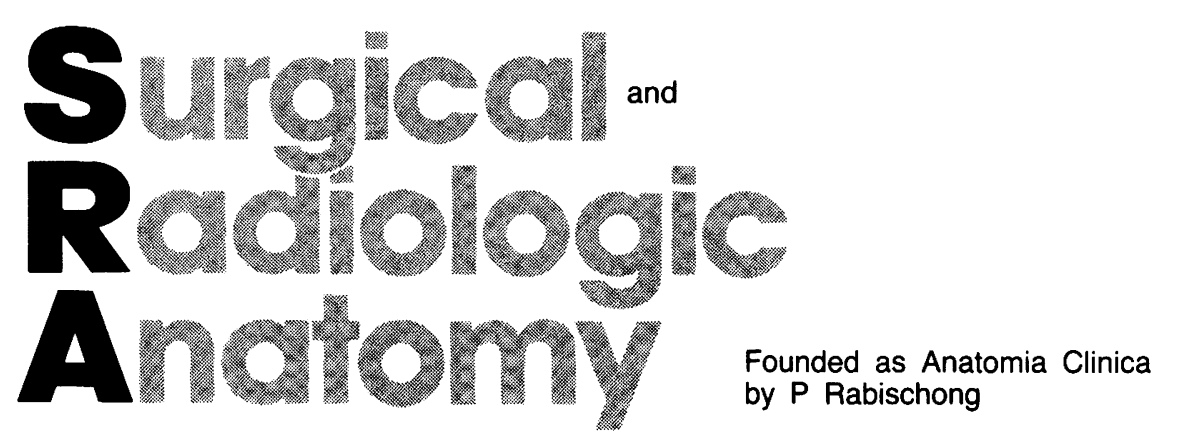

\section{Journal of Clinical Anatomy}

\section{Table of contents}

\section{Volume 15 Number 4, 1993}

Editorial

A discourse on the usefulness of anatomy

251

$P$ Dahhan

Anatomic bases of medical, radiological and surgical techniques

The cutaneous territory of the transverse tensor fascia lata flap: further anatomical considerations

M Medot, J Fissette

The sartorius myocutaneous island flap

ML Tang, XY Liu, JW Ren, DC Zhang, RS Li,

YM Wen, BF Ge

Anatomic basis of laparoscopic surgery in the male pelvis

O Cussenot, F Desgrandchamps, S Bassi,

P Teillac, JP Lassau, A Le Duc

Anatomic basis of lymphatic spread from carcinoma of the lung to the mediastinum: surgical and prognostic implications

M Riquet

\section{Original articles}

Cartilage degeneration in the human patellae $\quad 279$ and its relationship to the mineralisation of the underlying bone: a key to the understanding of chondromalacia patellae and femoropatellar arthrosis?

F Eckstein, R Putz, M Müller-Gerbl,

$M$ Steinlechner, KP Benedetto
The vertebral foramen:

287

a report concerning its contents

F de Peretti, I Hovorka, P Ganansia, JP Puch,

A Bourgeon, C Argenson

Pedicles of lumbar vertebrae

C Maillot, R Wolfram-Gabel

295

A tridimensional study using cuts at a low temperature of the infratemporal region

C Madrid, D Lefebvre, L Gineste, D Duran,

$R$ Combelles, with the collaboration of $P$ Roux,

$R$ Joly, A Laveran

Patterns of the coronary artery irrigation in the left ventricle

J Reig, A Jornet, M Petit

Anatomy of the seated position: methodologic approach and initial findings

S Ghannouchi, A Ghorbel, C Cavallero, J Bonnoit Interaction between the muscles of the neck and the extraocular muscles of the myopic eye. An electromyographic study

B Valentino, A Fabozzo

Reflections and suggestions on the nomenclature of the prostate

G Benoit, A Jardin, C Gillot

\section{Radiological anatomy}

Rotation of the cervical spinal column: a computed tomography in vivo study

J-L Dumas, M Sainte Rose, P Dreyfus,

D Goldlust, J-P Chevrel 


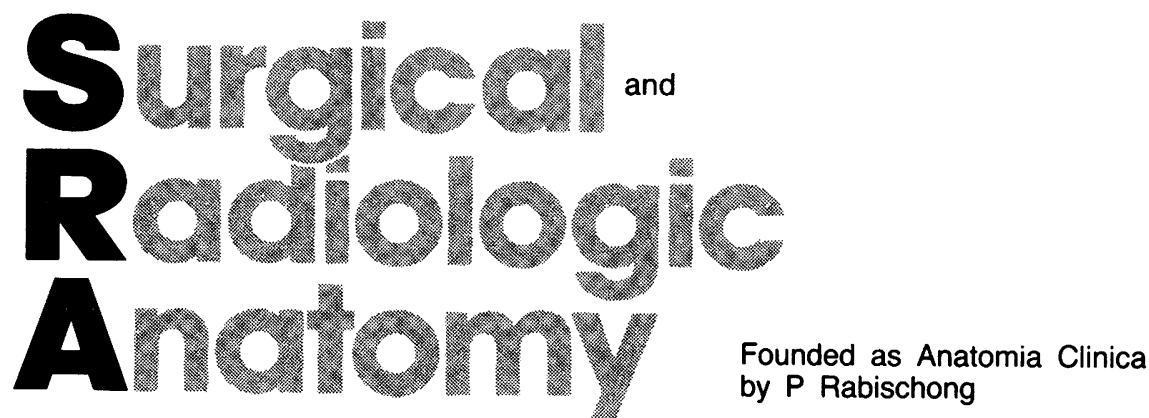

by $P$ Rabischong

\section{Journal of Clinical Anatomy}

\section{Table of contents}

Volume 15 Number 4, 1993 (continued)

Three-dimensional modeling of the anatomy 341 of heart and great vessels

D Chatel, Y Martin-Bouyer, C Acar, H Bouchoucha,

JL Sableyrolles, V Jebara, JC Chachques,

A Carpentier

Sonographic anatomy of the rectus sheath: $\quad 349$ an indication for new terminology and

implications for rectus flaps

QM Ali

\section{Anatomic variations}

Variations in arterial blood supply and

the risk of hemorrhage during percutaneous treatment of lesions of the pelviureteral junction obstruction: report of a case of testicular artery arising from an inferior polar renal artery V Ravery, O Cussenot, F Desgrandchamps, P Teillac, Y Martin-Bouyer, JP Lassau, A Le Duc

Middle mesenteric artery: an anomalous 361 origin of a middle colic artery

T Yoshida, S Suzuki, T Sato

A case of intraduodenal diverticulum imitating choledochocele

L Kovachev, T Deliisky, E Marinov

\section{Reports of the Société Anatomique de Paris}

The embryonic and early fetal development of the lymphatics of the heart and lungs in humans (25.6.93)

M Riquet, J Brière, P Dupont, G Pennhouat, G Hidden

EACA congress report, Munich 1993 371

Subject, author, referee and translator indexes

Chinese Journal

$264,270,278,308,320$ of Clinical Anatomy

Reviews in brief

$360,364,368$

Announcements
Books received

340,354 


\section{Collège Médical Français des Professeurs d'Anatomie}

This list of the members of the CMFPA will hereafter be updated every two years. The next revision, with the addresses of the members of the EACA, will appear in 1994.

La liste des membres du CMFPA sera désormais publiée tout les deux ans, avec la liste des membres de l'AEAC. La prochaine mise-à-jour aura lieu en 1994.

Aaron Claude
$(1971) *$
Alexandre Jean-Henri
$(1966)$

UFR Cochin-Port-Royal Anatomie, 24, rue du Faubourg Saint-Jacques, 75674 Paris 1.43.20.12.40

Dom. : 131, rue de la Santé, 75013 Paris 1.45.89.22.06 (1966)

Ameil Marc

Service de Chirurgie, Hôpital Broussais, 96, rue Didot, 75014 Paris - 1.43.95.95.95 ou 1.45.42.22.06

Dom. : 3, avenue Robert Schumann, 92100 Boulogne - 1.46.04.43.70

\section{Aprosio Norbert (1961) \\ Argème Maxime (1970) \\ **Argenson Claude (1972)}

Faculté de Médecine, 51, rue Cognacq-Jay. 51096 Reims Cedex; et Service de Chirurgie Orthopédique et Traumatologique, 45 , rue Cognacq-Jay, 51082 Reims Cedex 26.78.76.71

Dom. : 56, avenue Paul-Marchandeau. 51000 Reims

Armstrong Olivier

Autissier Jean (1971)

Avisse Claude

Bailleul Jean-Pierre (1985)

\section{$k *$ Barbin Jean-Yves (1961)}

Institut d'Anatomie Normale, Faculté de Médecine, 4, rue Kirschleger, 67085 Strasbourg Cedex - 88.35.87.90

Faculté de Médecine, Anatomie, Secteur Nord, 2, boulevard Pierre-Dramard, 13326 Marseille Cedex 3-91.69.88.21 ou 91.69.88.23

Dom. : 14, boulevard Henri-Fabre, 13012 Marseille - 91.34.29.97

Dom. : Moulin des Baux. 13260 Cassis

Laboratoire d'Anatomie, Faculté de Médecine, 1. rue Gaston-Veil, 44035 Nantes 40.41.28.10

Faculté de Médecine, 1. boulevard Jeanned'Arc, 21000 Dijon - 80.65.23.23

Dom. : 37, rue J.-B. Baudin, 21000 Dijon 80.66.25.65

Laboratoire d'Anatomie, Faculté de Médecine, 51, rue Cognacq-Jay, 51095 Reims Cedex; et Debré, rue Alexis-Carrel, 51092 Reims Cedex $-26.78 .71 .20$

Dom. : 1, rue de Savoye, 51100 Reims 26.88.64.33

Laboratoire d'Anatomie, Faculté de Médecine, 1, place de Verdun, 59045 Lille Cedex 20.62.69.4I - IUFP : 20.60.07.17

Dom. : 7 , avenue Foch, 59130 Lambersat 20.92.20.01

Laboratoire d'Anatomie, Faculté de Médecine. 1 , rue Gaston-Veil, 44035 Nantes 40.41.21.36

Dom. : La Turballière, Sucé sur Erdre, 44240

La Chapelle sur Erdre - 40.77.71.45 Service de Chirurgie Générale, Hôpital R.-
Bargy Frédéric
(1988)

Bastian Dominique

Bastide Guy

(1961)

Baulac Michel

(1988)

Bécade Philippe

Bécue Jean

(1974)

Béjui Jacques (1986)

Benhamou-Mayoux Marie-Anne

Benoit Gérard (1986)

Berthelot Jean-Louis

Bonnel François (1974)

Bonnoit Jean (1976)

* La date entre parenthèses est celle de la nomination à l'agrégation. ** Membre honoraire

Faculté Cochin-Port-Royal, 24, rue du Faubourg Saint-Jacques, 75014 Paris 1.44.41.23.60 (Fax : 44.41.22.23)

Dom. : 19, rue d'Arcole, 75004 Paris 1.43.26.27.80

Laboratoire d'Anatomie, Faculté de Médecine Saint-Louis-Lariboisière, 45 , rue des SaintsPères, 75270 Paris Cedex 06 - 1.42.86.20.47 Dom. : 14, rue de Vouillé. 75015 Paris 1.48.56.02.93

Laboratoire d'Anatomie, Faculté de Médecine, 133, route de Narbonne, 31077 Toulouse Cedex - 61.53.23.13, P. 341 ou 61.55.03.68 Hôp : 61.77.20.59

Dom. : 10, rue des Châlets, 31000 Toulouse 61.62 .83 .48

Laboratoire d'Anatomie, Faculté de Médecine Pitié-Salpêtrière, 105. boulevard de l'Hôpital. 75013 Paris - 1.40.77.97.22 (direct) ou 1.45.70.27.37 (direct Neuro. à l'Hôpital)

Clinique du Pont de Chaume, 330, avenue Marcel Unal, 82017 Montauban Cedex 63.68.34.50

Laboratoire d'Anatomic. Faculté de Médecine de Toulouse, 133, route de Narbonne, 31062 Toulouse Cedex - 61.55.03.68; ou CHU Rangueil, 31054 Toulouse - 61.32.27.51 Dom. : 299, avenue J.-Rieux, 31500 Toulouse $-61.20 .48 .64$

Laboiratoire d'Anatomie, Faculté AlexisCarrel, 8, rue Guillaume-Paradin, 69008 Lyon - 78.77.86.23 (Fax : 78.77.87.01)

Dom. : 52, rue du Lieutenant-Colonel-Prévost, 69006 Lyon - 78.89.76.44 (Fax : 72.12.00.04)

Faculté de Médecine Cochin-Port-Royal, 24. rue du Faubourg Saint-Jacques, 75014 Pairs 1.43.20.12.40

Service Urologie, Hôpital Kremlin-Bicêtre, 78. rue du Général Leclerc, 94270 Le KremlinBicêtre - 1.45.21.36.94; et UFR des SaintsPères, 45, rue des Saints-Pères, 75720 Paris Cedex 06 - 1.42.86.20.47

Dom. : 1, rue Barye, 75017 Paris 1.43.80.70.25

Faculté Xavier-Bichat. 16, rue Huchard. 75018 Paris - 1.42.63.84.20

Dom. : Parc de Maugarny, 95680 Montlignon - 1.34.16.63.00

Faculté de Médecine, 2, rue de l'Ecole de Médecine, 34060 Montpellier Cedex - CHU : 67.33.87.26

Dom. : $11 / 4$, avenue de la Pompignage, 34000 Montpellier - 67.79.06.19

Laboratoire de Biomécanique Appliquée, Faculté de Médecine. Secteur Nord, 2 boulevard P.-Dramard, 13326 Marseille Cedex 15 91.51.09.67 (Fax : 91.51.12.55)

Dom. : 2, rue Saint-Bazile, 13001 Marseille 91.95.76.70 


\title{
Cartilage degeneration in the human patellae and its relationship to the mineralisation of the underlying bone: a key to the understanding of chondromalacia patellae and femoropatellar arthrosis?
}

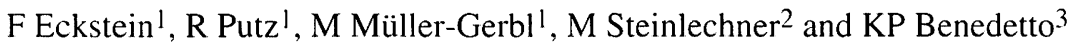 \\ 1 Anatomische Anstalt, Pettenkoferstr. 11, D-80336 München, Germany \\ 2 Institut für Anatomie, Müllerstr. 59, A-6010 Innsbruck. Austria \\ ${ }^{3}$ Universitätsklinik für Unfallchirurgie, Anichstr. 35. A-6020 Innsbruck. Austria
}

Summary. According to the literature subchondral bone plays a significant role in the transmission of load through joints and in the pathogenesis of osteoarthrosis. Therefore the degeneration of the articular cartilage was investigated in the patellae from 30 dissecting-room specimens and of 20 patients, previously submitted to arthroscopy, and subchondral mineralisation of their underlying bone was at the same time assessed by means of CT osteoabsorptiometry. Lateral cartilage lesions were localised over highly mineralised subchondral bone; these appear to be due to long-term stress. They were mainly found in the older specimens and showed a high rate of progression with increasing age. Medially localised cartilage lesions, on the other hand, were situated in a transitional region between moderate and slight subchondral mineralisation; they may be caused by infrequent stress peaks and by shear stress in the articular cartilage, the very medial part of the joint being deprived of mechanical stimulation for much of the time. These lesions

Correspondence to : F Eckstein were to be found predominantly in the younger specimens and showed little progress with advancing age. Patients with lateral cartilage degeneration exhibited higher, patients with medial chondromalacia patellae lower mineralisation than normals. Their density patterns therefore indicate a different mechanical pathogenesis of the cartilage lesions in the lateral and medial facet. It could be shown that CT osteoabsorptiometry allows an assessment of the mechanical situation, present in individual femoro-patellar joints, and that this situation is highly relevant for the pathogenesis of patellar cartilage degeneration.

Etude de la relation entre la dégénérescence cartilagineuse et la minéralisation de l'os sous-chondral de la patella. Est-ce une façon pour comprendre la pathogénie de la chondromalacie patellaire et de l'arthrose fémoro-patellaire?

Résumé. Selon la littérature, l'os sous-chondral joue un rôle important dans la transmission des forces à travers les articulations et dans la patho- génie de l'arthrose. C'est pourquoi la dégénérescence du cartilage articulaire a été étudiée sur les patellas de 30 sujets anatomiques et de 20 patients venant de subir une arthroscopie et dont la minéralisation sous-chondrale de l'os sous-jacent avait été appréciée au même moment par absorptiométrie osseuse par scanner. Les lésions cartilagineuses latérales étaient situées sur de l'os sous-chondral fortement minéralisé ; elles paraissent êtres dues à des contraintes à long terme. Elles furent principalement trouvées sur les spécimens âgés et montraient un fort taux de progression en fonction du vieillisement. A l'opposé, les lésions cartilagineuses médiales étaient situées dans une région de transition entre des minéralisations modérée et faible ; elles pourraient être dues à des pics de contrainte intermittents et à des contraintes en cisaillement sur le cartilage articulaire, la partie la plus médiale de l'articulation étant privée de stimulations mécaniques la plupart du temps. Ces lésions furent trouvées essentiellement sur les sujets les plus jeunes et montraient peu de progression avec le vieillissement. Les patients présentant une dégénérescen- 
ce cartilagineuse latérale avaient une minéralisation supérieure à la normale, les patients présentant une chondromalacie médiale avaient une minéralisation plus faible que la normale. La distribution de la densité indique donc un mécanisme pathogénique différent pour les lésions cartilagineuses sur les facettes latérale et médiale. L'absorptiométrie osseuse par scanner permettrait donc d'apprécier la situation mécanique individuelle de chaque articulation fémoropatellaire. Cette situation est fortement corrélée à la pathogénie de la dégénérescence du cartilage patellaire.

Key words: Patella - Cartilage degeneration - Subchondral mineralisation - Chondromalacia patellae - Femoropatellar arthrosis

It is widely accepted that mechanical factors play an important part in the initiation and progression of osteoarthrosis in general and chondromalacia of the patella in particu$\operatorname{lar}[11,25]$. Nevertheless, the exact nature of the mechanism leading to joint damage, and the exact localisation of the initial changes in cartilage degeneration are still a matter of discussion and disagreement [17]. Radin and Paul [26] and Radin et al [28] were able to show that the ability of a joint to attenuate "longitudinal impact loading", which is an important factor in the pathogenesis of osteoarthrosis [27], is principally determined by the stiffness of the subchondral bone. As against this, the articular cartilage is supposed to contribute to reducing friction during movements of the joint. These authors even suggest that it is a change in the nature of the subchondral bone, i.e. an increase in its stiffness, which represents the first step in the development of osteoarthrosis [29]. Up to now it has not been possible to assess such changes in the living satisfactorily. Subchondral sclerosis, although accepted as a criterion for the radiological diagnosis of osteoarthrosis, does not permit quantitative evaluation of the relative distribution of subchondral mineralisation in the joint surface to be made. However, computed tomography osteoabsorptiometry (CT-OAM) [18, 19] has recently provided a method for assessing the surface distribution of subchondral mineralisation in the living subject in terms of the Hounsfield scale. We were able to establish in a previous investigation [5] that the pattern of mineralisation in the patella does in fact reflect the biomechanical situation present in the femoropatellar-joint. According to Hvid et al [12], the mechanical properties (and particularly the stiffness) of the subchondral bone can, with certain reservations, be inferred from this mineralisation pattern. The aim of this investigation is therefore to compare the localisation of macroscopically visible cartilage degeneration with the radiological (CT osteoabsorptiometric) density of the underlying bone in the human patella, which according to Ficat and co-workers $[7,8]$ offers an "observatoire ideal" of arthrotic degeneration.

\section{Material and methods}

We first examined 30 formalin-fixed specimens of the knee-joint taken from dissecting-room subjects, selecting the youngest subjects available. Those with systemic disease of the locomotor apparatus or severe arthrosis of the knee-joint were excluded from the investigation. The ages of the 7 female and 23 male subjects ranged from 47 to 90 years. We divided these into two groups: 15 specimens of less than 60 years (mean age 53) constituted Group Y, and 15 of more than 60 years (mean age 74) Group O. Twenty patients were then selected from the Depart- ment of Surgery, on whom arthroscopy had been carried out for various reasons (mostly because of suspected damage to the meniscus). In each case, a CT osteoabsorptiometric examination was made within $48 \mathrm{~h}$ of arthroscopy. The criterion for inclusion was the presence of circumscribed damage of grades 1 or 2 [21] to the articular cartilage of the medial or lateral facet, or of the primary ridge. There were no gross changes in the AP, or lateral radiographs, nor any severe disease of the femoropatellar-joint. Nine women and eleven men between the ages of 16 and 61 were examined, the average age being 31 years.

\section{Investigation of \\ the subchondral mineralisation}

The knee-joint specimens and the knees of the arthroscopy patients ( $30^{\circ}$ of knee-flexion) were examined in a CT scanner (Siemens Delta scan 50 FS 2). Sectional images between the upper pole of the patella and the tibial plateau were made at intervals of $4 \mathrm{~mm}$. CT osteoabsorptiometry $[18,19]$ was used to obtain isodensities (i.e., contour lines joining points of equal density). The projection of their subchondral extension was marked on the surface of each section, and these marks transferred into the corresponding position of the section in a template of the articular surface (Fig. la). Six Hounsfield ranges ( $<400 \mathrm{HU}->800 \mathrm{HU}$ ) were reconstructed for the specimens, and seven ( $<300$ HU $->1050)$ for the patients. The distribution pattern was then digitalised (Hewlett Packard, Scan Jet Plus) and read into an Apple Macintosh Computer, where it was provided with standardised grey values (Fig. 1b), using a grey scale of 256 steps. Image summation was finally carried out in the computer in order to produce average pictures. By means of program software, the original pictures were laid together successively in pairs, one upon the 

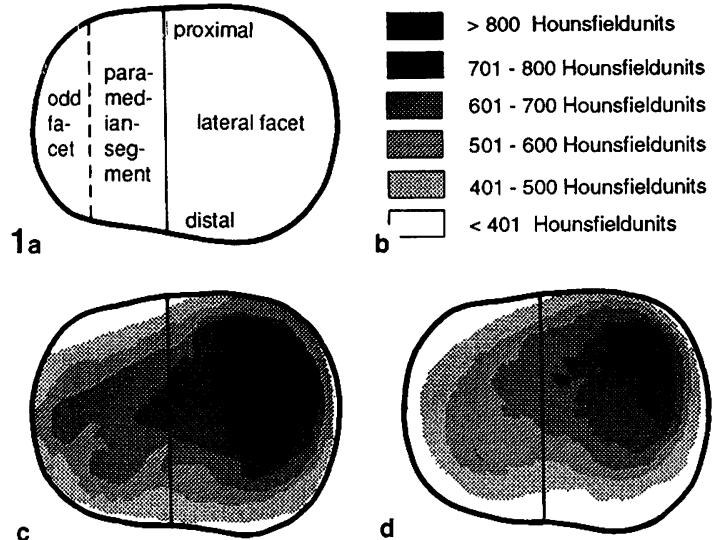

C
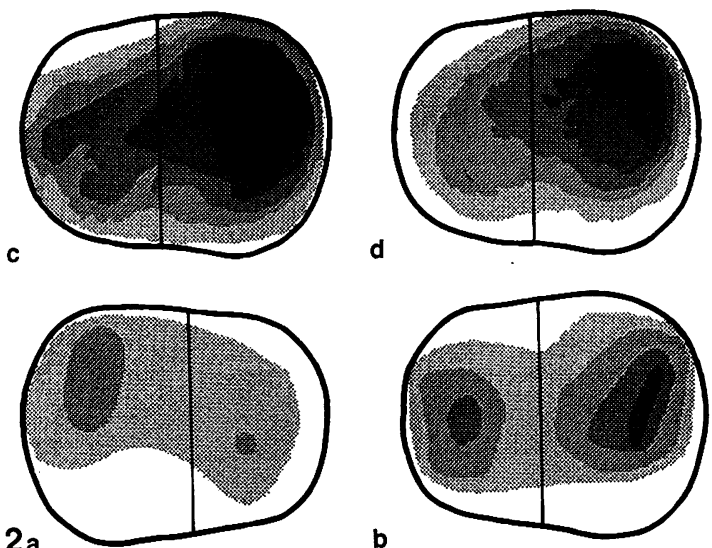

b
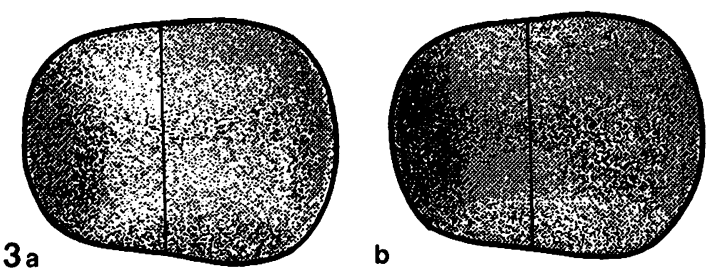

Figs. 1a-d, 2a, b, 3a, b 1a Outline template of the articular surface of the patella built up from measurements of 30 specimens. b Grey values of the Hounsfield ranges examined in the specimens. c Summation picture for Group Y (age < 60 yrs, $\mathrm{n}=15$ ). d Summation picture for Group $\mathrm{O}$ (age $>60$ yrs, $n=15$ ). 2 Surface distribution of subchondral mineralisation in the patella of a patient suffering from left-sided poliomyelitis. a Left patella. b Right patella. 3 Surface distribution of cartilage degeneration in the patellae of 30 anatomical specimens. white. intact cartilage; grey, mild degeneration (degree 1); black, severe cartilage damage (degree $>1$ ). a Summation picture for Group Y (age $<60$ yrs, $n=15$ ). b Summation picture for Group O (age > 60 yrs, $n=15$ )

1a Tracé du contour de la surface articulaire de la patella. bâti à partir des mesures de 30 spécimens. b Echelle des gris des niveaux de densité Hounsfield trouvés sur les spécimens. c Shéma récapitulatif pour le Groupe Y (âge $<60$ ans, 15 cas). d Shéma récapitulatif pour le groupe $O$ (âge $>60$ ans, 15 cas). 2 Distribution de la minéralisation sous-chondrale sur les patellas d'un patient atteint de poliomyélite latéralisée à gauche. a Patella gauche. b Patella droite. 3 Distribution de la dégénérescence cartilagineuse sur les patellas de 30 spécimens anatomiques. Blanc, cartilage intact; gris, dégénérescence légère (degré 1); noir, dégâts cartilagineux sévères (degrés $>1$ ). a Shéma récapitulatif pour le groupe $Y$ (âge $<60$ ans. 15 cas). b Shéma récapitulatif pour le groupe $O$ (âge $>60$ ans. 15 cas)

other, and the grey values of corresponding pixels were fused to a value lying exactly between them in the grey scale. Intermediate grey values obtained from the single summation steps were redefined in a final step as the closest neighbouring grey value in order to restore the original isodensities.

\section{Examination of \\ the cartilage degeneration}

The grade [21] and extent of the cartilage degeneration in the patellae of the 30 specimens were pictorially recorded, using the joint template mentioned above. The distribution pattern was digitalised, and distinguishing grey values allotted to the different degrees of degeneration. In this case, the computergraphic method for producing the summation pictures depended upon a program which at each step picked up 50\% of the pixels from each of two originals. in this way, the grey value of the pixels reveals, as in the single pictures, the degree of cartilage degeneration, and their density the frequency of the cartilage damage in the corresponding area of the joint. The grade and localisation of the cartilage degeneration in the patients was recorded on an arthroscopy form. In the summation pictures obtained
Comparison of

the subchondral mineralisation

with the cartilage degeneration

After comparison of the distribution patterns in the single pictures, the grades of cartilage degeneration and the locally corresponding Hounsfield range were read from 38 measuring points regularly distributed over the articular surface. The percentage distributions of grades of cartilage degeneration in the Hounsfield ranges were calculated for all the specimens added together, and the level of significance of the differences between the density ranges statistically tested. The percentage distribution of the grade of cartilage degeneration in the different Hounsfield ranges was also determined separately for Groups $\mathrm{Y}$ and $\mathrm{O}$. Differences in the percentage of severe cartilage damage present in the Hounsfield ranges of the two groups were tested for statistical significance.

\section{Results}

\section{Subchondral mineralisation}

Maximum subchondral mineralisation was found in the proximal part of the lateral facet in all the patellae examined. This amounted in the anatomical specimens to $600-1000 \mathrm{HU}$, and in the patients to $450-1100 \mathrm{HU}$, and decreased more or less steeply towards the periphery. Whereas there was little difference in the principal distribution of the mineralisation (high density, lateral; low density, medial) in Groups Y (Fig. lc) and O (Fig. ld), the younger individuals displayed a slightly greater mineralisation of the subchondral bone (shown by the somewhat wider extension at all density levels). In one 33 year-old patient, who had suffered from poliomyelitis from the age of four years, and in whom there was marked muscle wasting of the whole left lower limb, the right patella (Fig. 2) was more highly mineralised than the left by $300 \mathrm{HU}$. 

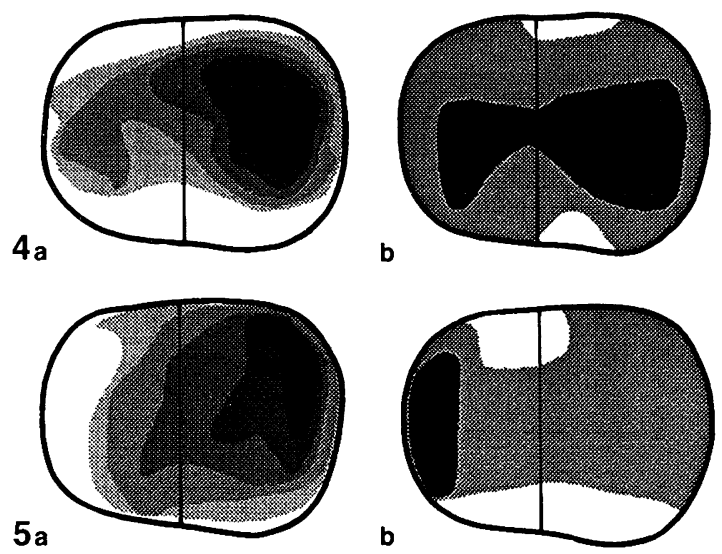

Figs. 4a, b, 5a, b

4 Single example of lateral cartilage damage over highly mineralised subchondral bone. a Surface distribution of subchondral mineralisation. b Surface distribution of cartilage degeneration. white, intact cartilage; grey, mild degeneration (degree 1); black, severe cartilage damage (degree > 1). 5 Single example of medial cartilage damage over poorly mineralised subchondral bone. a. Surface distribution of subchondral mineralisation. b Surface distribution of cartilage degeneration white, intact cartilage; grey; mild degeneration (degree 1); black, severe cartilage damage (degree $>1)$

4 Exemple de dégâts cartilagineux latéraux sur de l'os sous-chondral fortement minéralisé. a Distribution de la minéralisation sous-chondrale. b Distribution des lésions cartilagineuses dégénératives. Blanc, cartilage intact; gris, dégénérescence légère (degré 1); noir, dégâts cartilagineux sévères (degrés $>1$ ). 5 Exemple de dégâts cartilagineux médiaux sur de l'os sous-chondral faiblement minéralisé. a Distribution de la minéralisation sous-chondrale. b Distribution des lésions cartilagineuses dégénératives. Blanc, cartilage intact; gris, dégénérescence légère (degré 1); noir. dégâts cartilagineux sévères (degrés $>1$ )
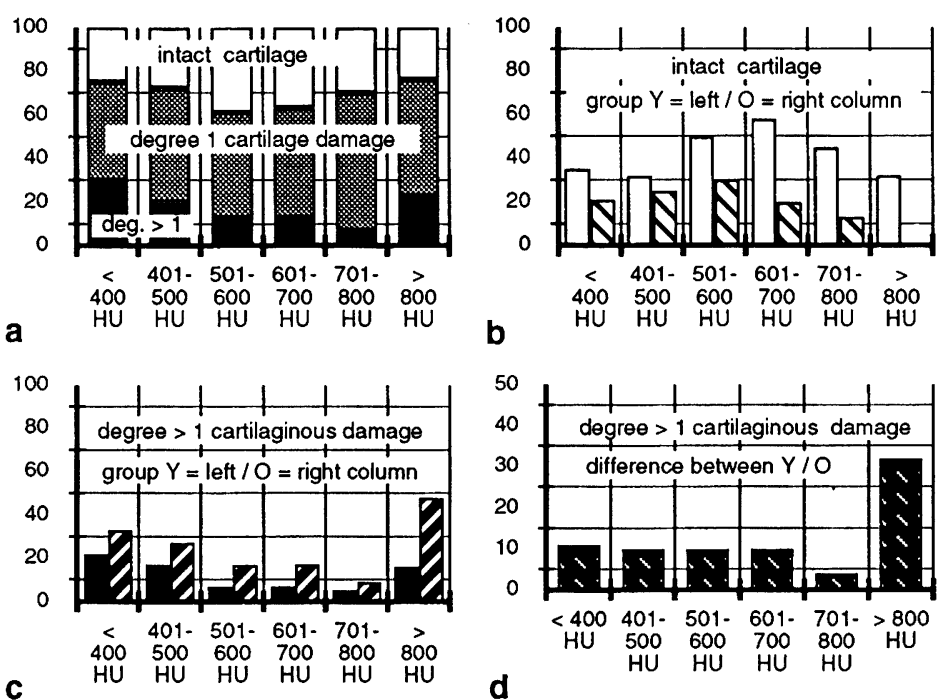

Fig. 6a-d

a Percentage distribution (\% total articular surface) of intact cartilage, mild damage (degree 1) and severe damage (degree $>1)$ in the Hounsfield ranges $(<400 \mathrm{HU}->800 \mathrm{HU}$ ) from all 30 anatomical specimens. b Percentage distribution of intact cartilage in Group Y (age $<60 \mathrm{yrs} / \mathrm{L}$ cols) and Group O (age > 60 yrs / R cols) in the different Hounsfield ranges. c Percentage distribution of severe cartilage degeneration (degree $>1$ ) in Group Y (L cols) and Group O (R cols) in the different Hounsfield ranges. d Difference in the percentage of severe cartilage degeneration (degree $>1$ ) between Groups $\mathrm{Y}$ and $\mathrm{O}$ in the different Hounsfield ranges

a Distribution en pourcentage (rapporté à la surface articulaire totale) du cartilage intact, des lésions légères (degré 1 ) et des dégâts sévères (degrés $>1$ ) dans les niveaux de densité Hounsfield $(<400 \mathrm{HU}->800 \mathrm{HU})$ de 30 spécimens anatomiques. b Distribution en pourcentage du cartilage intact dans le groupe $\mathrm{Y}$ (âge $<60$ ans, colonnes de gauche) et du groupe $\mathrm{O}$ (âge $>60$ ans, colonnes de droite) dans les différents niveaux de densité Hounsfield. c Distribution en pourcentage des lésions cartilagineuses sévères (degrés > 1) dans le groupe Y (colonnes de gauche) et dans le groupe $\mathrm{O}$ (colonnes de droite) dans les différents niveaux de densité Hounsfield. d Différence dans les pourcentages des dégénérescences cartilagineuses sévères (degrés supérieurs à 1 ) entre les groupes $\mathrm{Y}$ et $\mathrm{O}$ dans les différents niveaux de densité Hounsfield

\section{Cartilage degeneration}

Although the pattern of subchondral mineralisation is relatively constant, the localisation of the cartilage degeneration, both in individuals and on comparison between the age groups, is rather variable. In the younger group, degeneration predominates medially and peripherally in the joint (Fig. 3a), whereas central lesions of the lateral facet and near the principal ridge become more noticeable with advancing age (Fig. 3b).

\section{Comparison of \\ subchondral mineralisation \\ with cartilage degeneration}

It can be shown in individual cases that degeneration of the lateral facet (Fig. 4b) is localised over areas of greater subchondral mineralisation (Fig. 4a), whereas lesions in the medial compartment (Fig. 5b) are found together with a lower density (Fig. 5a). If one examines the distribution of the grades of cartilage degeneration throughout different Hounsfield ranges (Fig. 6a), it is obvious that the articular cartilage is less often intact, and more often severely damaged, over regions of both very high and very low density than in association with bone showing an average amount of subchondral mineralisation $(p<0.01)$. If the distributions for Groups $\mathrm{Y}$ and $\mathrm{O}$ are examined separately, differences in the amount of intact (Fig. 6b) and severely damaged cartilage present (Fig. 6c) can be observed. The difference in the percentage of severe cartilage degeneration ( $>$ grade l) between the two age groups is less at a level below $800 \mathrm{HU}$ (average difference $=9 \%$ of the surface area) than above this figure (difference between Groups $\mathrm{Y}$ and $\mathrm{O}=$ $29 \%$ ). This difference is significant at a level of $1 \%$. In the group of arthroscopy patients without cartilage degeneration the summation picture for subchondral mineralisation displays a considerable island peak of bone den- 


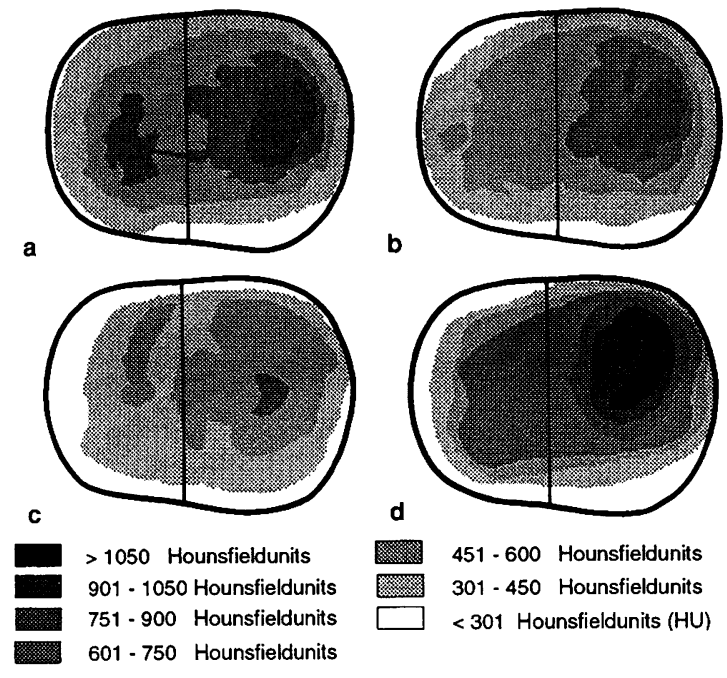

Fig. 7a-d

Surface distribution of subchondral mineralisation in the patellae of patients examined arthroscopically. a Summation picture for group without cartilage degeneration $(n=6)$. b Summation picture for group with central cartilage degeneration $(n=8)$. c Single example of patient with medial cartilage degeneration. d Single example of patient with lateral cartilage degeneration

Distribution de la minéralisation sous-chondrale des patellas des patients examinés par arthroscopie. a Shéma récapi-

tulatif pour le groupe sans lésion cartilagineuse ( 6 cas). b Shéma récapitulatif pour le groupe présentant des lésions cartilagineuses centrales (8 cas). c Exemple d'un patient avec une dégénérescence cartilagineuse médiale. $\mathbf{d}$ Exemple d'un patient avec une lésion cartilagineuse latérale

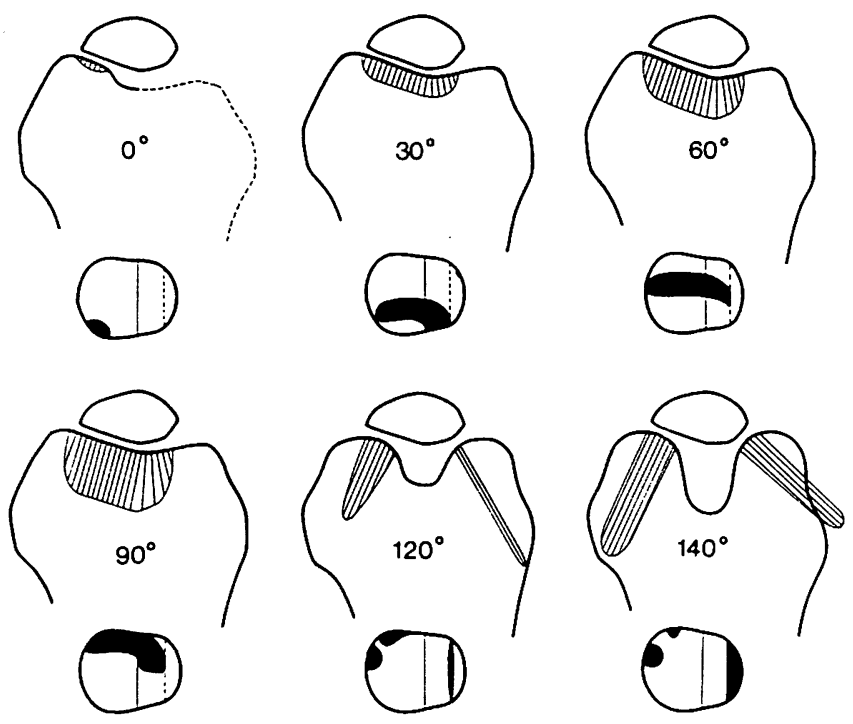

Fig. 8

Distribution of stress in the femoropatellar-joint based on the contact areas determined by Hehne (1983) and the joint forces calculated by Maquet (1976)

Distribution des contraintes sur l'articulation fémoro-patellaire, basée sur les aires de contact déterminées par Hehne (1983) et les forces articulaires calculées par Maquet (1976)

sity at the secondary ridge (Fig. 7a). This is not seen in patients with central damage to the tissue (Fig. 7b). The single example of a patient with medial degeneration reveals significantly reduced mineralisation of the joint (Fig. 7c), whereas in a patient with lateral degeneration bone density is raised to a remarkable extent (Fig. 7d).

\section{Discussion}

\section{Subchondral mineralisation}

CT osteoabsorptiometry gives a picture of the mineralisation in the arthroscopy patients which agrees well with information obtained from the anatomical specimens [5], and makes it possible to take similar measurements in the living subject. Taking into consideration the contact areas described in the literature [11] one can interpret the density maxima in the proximal part of the lateral facet as the expression of more frequent contact under intensive loading. Whereas the proximal lateral facet is in contact in all positions of the knee-joint greater than $60^{\circ}$, medially there is a changeover from the paramedian segment $\left(90^{\circ}\right)$ across the secondary ridge $\left(120^{\circ}\right)$ to the "odd facet" $\left(140^{\circ}\right)$. Taking into account the significant increase in force exerted by the quadriceps as flexion increases [16], the finding of higher mineralisation in the proximal part of the lateral facet and a lower density medially and distally becomes plausible (Fig. 8). In this way, the density distribution can be explained in terms of the principal stress [22] or the "loading history" of a joint [3], which makes it possible to infer the long-term distribution of load from the pattern of mineralisation. The situation in the patient with poliomyelitis confirms that the degree of mineralisation is determined by the magnitude of the mechanical stress acting on the joint, and that the bone reacts with atrophy or hypertrophy to changes in the mechanical environment, as was suggested by Kummer [15]. These findings are also in agreement with the observations of Müller Gerbl et al [20], who were able to show that, following a corrective osteotomy at the knee joint, the density of the tibial plateau at first decreases, probably due to a decrease in activity of the patient. About one year later the distribution pattern has changed in comparison with the preoperative situation, indicating a more central position of the resultant joint force. The slightly higher bone density found in the younger age group may be attributed to the greater physical activity of these people, which is also suggested by the more striking extension of 
the highly mineralised regions towards the secondary ridge in the younger subjects. These findings suggest that information on the distribution of the subchondral mineralisation and the position of the maxima is obtainable with CT-OAM and that the method allows a quantitative assessment of the degree of mineralisation of the joint to be made. It is also clear that, compared with the conventional AP, lateral or tangential radiograph, the method provides a great deal more information on the overall biomechanical conditions of an individual joint.

\section{Cartilage degeneration}

The localisation of the cartilage degeneration agrees with that reported in the literature. The damage associated with the "odd facet", which is more common than lateral lesions $[4,9]$ is frequently found in young people [6]. Lesions of the lateral facet [8] predominantly appear, however, with advancing age [33].

\section{Comparison of subchondral mineralisation with cartilage degeneration}

The greater degree of mineralisation of the lateral facet suggests that the cartilage degeneration found there may be due to intense and prolonged stress acting on this region of the joint. A similar conclusion followed the clinical and radiological investigations of Ficat et al [7] and Ficat and Hungerford [8], who described a "lateral hyperpression-syndrome" in the patella. They attributed this pathological entity to functional dominance of the lateral retinaculum, due to imbalance between the action of the vastus lateralis and medialis. It has also been demonstrated in animals that, following a proximal tibial osteotomy, the mechanical overloading of a single joint compartment can induce degenerative changes [10], and that these are associated with increased density of the subchondral bone [35]. Radin et al [29] put forward the theory that the initial step towards arthrosis may be caused by stiffening of the subchondral bone due to microfractures and microcallus formation. This is supposed to lead to excessive mechanical demands being made upon the overlying cartilage. The similarity of the observed mineralisation pattern with the distribution of stiffness (determined by means of compression tests) in the subchondral bone of the human patella [32] and the high correlation between CT measurements of the density of the subchondral bone and its mechanical stiffness [12], suggest a connection between an increase in density and stiffening. The degeneration of the articular cartilage over the highly mineralised lateral patellar facet may therefore indeed be due to an increase in stiffness of its subchondral bone. The high percentage of degenerate cartilage, however, localised over slightly mineralised subchondral bone particularly found over the medial facet, is difficult to reconcile with the mechanism described above. Abernethy et al [I] and Radin and Rose [30] further developed the theory mentioned above and suggested that the initiation of cartilage degeneration might rather be due to "stiffness gradients" in the subchondral bone. They hypothesised that the articular cartilage is submitted to significant vertical shear forces at boundary regions between more and less elastic bone. The assumption that gradients in the stiffness of the subchondral bone can damage cartilage in this way agrees very well with our finding of steep density gradients in the periphery of the patella. This concerns particularly the medial facet, where there is a strong tendency towards early degeneration. It is also true that the medial facet is subjected to high stress peaks when the knee is fully flexed [11, 34], and animal experiments have shown that short peaks of transarticular loading may result in degeneration of the cartilage [31]. As may be concluded from the low degree of mineralisation of the medial facet, these peaks do not occur very often. The presence of high stress peaks in a part of the joint which is otherwise not subjected to heavy loading could in our opinion bring about an unsatisfactory mechanical environment, in which the joint may not be able to adapt functionally to such mechanical demands, for example by increasing the thickness of the articular cartilage [14]. This is in agreement with our own findings [5], in which we were able to show that cartilage is usually thicker in the lateral part of the femoropatellar joint than in the medial. The low density and considerable elasticity [1] of the underlying subchondral bone may account for the fact that the lesions on the medial side are only slightly progressive; in other words, not very likely to lead to the more severe forms of cartilage degeneration. According to Goodfellow et al [9] softening of the articular cartilage in this region may even be considered as a normal variant in adolescents. The more progressive nature of cartilage degeneration over regions of highly mineralised areas, on the other hand, may be due to the greater stiffness of the subchondral bone and its reduced capacity for shock absorption $[23,24,30]$. This might also account for the fact that the milder forms of chondromalacia patellae are much more common on the medial side of the joint $[4,21]$, while the more severe examples of femoropatellar arthrosis are almost exclusively lateral $[8,13]$. The findings in the arthroscopy patients confirm these conclusions. We regard the marked island-shaped increases in density near the secondary ridge in the group without degeneration of the patellar cartilage 
as a result of the "point-like" opposition of the patellae to the femur at $120^{\circ}$ of flexion $[11,34]$. The relatively high density here suggests that these people frequently bend their knees. Since this secondary maximum is not found in patients with central cartilage degeneration, it is plausible that there exists a different mechanical enviroment in this group. It is possible that less frequent full flexion contributes to degeneration of the articular cartilage due to a relative lack of intermittent pressure. This is in accordance with the finding of Alexander [2] that there is a positive correlation failure to take advantage of the full range of physiological movement available at a joint and its susceptibility to osteoarthritis. Comparing the patients with severe medial and lateral cartilage degeneration suggests that the less than average mineralisation in the case of medial cartilage damage may be the result of too few general mechanical demands made on the joint, and the very high degree of mineralisation in the case of lateral damage the result of excessive use.

We conclude from these findings that the subchondral mineralisation assessed by means of CT osteoabsorptiometry provides relevant data on the mechanics of a joint, and that it may give some insight into the pathogenesis of cartilage degeneration which cannot be provided by the conventional radiological techniques. We believe that the gain in information on the mechanical condition of an individual joint justify applying this method now to the femoropatellar joint in clinical practice.

Acknowledgements. Our grateful thanks are due to Professor W. Platzer, Director of the Department of Anatomy, University of Innsbruck, for generally putting the specimens at our disposal and for making the computer tomographic exposures possible on the scanner of the institute. We thank Dr. F. Steel for the translation of the manuscript and $H$. Ruß for the drawing of Figure 8.

\section{References}

I. Abernethy PJ, Townsend PR, Rose RM, Radin EL (1978) Is chondromalacia patellae a separate clinical entity? J Bone Joint Surg [Br] 6 : 205-210

2. Alexander $\mathrm{Cl}$ (1989) Relationship between the utilisation profile of individual joints and their susceptibility to primary osteoarthrosis. Skeletal Radiol 18 : 199 205

3. Carter DR (1984) Mechanical loading histories and cortical bone remodelling. Calcif Tissue Res 36 : 519-524

4. Dashefsky JH (1987) Arthroscopic measurement of chondromalacia of patella cartilage using a microminiature pressure transducer. Arthroscopy $3: 80-85$

5. Eckstein F. Müller-Gerbl M, Putz R (1992) Distribution of subchondral bone density and cartilage thickness in the human patella. J Anat 180:425-433

6. Emery IH, Mechim G (1973) Surface morphology and topography of patellofemoral cartilage fibrillation in Liverpool necropsies. J Anat 116: 103-120

7. Ficat P, Ficat C, Bailleux A (1975) Syndrome d'hyperpression externe de la rotule (SHPE). Son intérêt pour la connaissance de l'arthrose. Rev Chir Orthop $61: 39-59$

8. Ficat P, Hungerford DS (1977) Disorders of the patellofemoral joint. Masson, Paris

9. Goodfellow J, Hungerford DS, Woods C (1976) Patello-femoral joint mechanics and pathology. Chondromalacia patellae. J Bone Joint Surg $[\mathrm{Br}] 58$ : 291-299

10. Goodman SB, Lee J, Smith RL, Csongradi JC, Fomasier VL (1991) Mechanical overload of a single compartment induces early degenerative changes in the rabbit knee: a preliminary study. J Invest Surg $4: 161-170$

11. Hehne HJ (1983) Das Patellofemoral gelenk. Enke. Stuttgart

12. Hvid I, Bentzen SM, Linde F, Mosekilde L, Pongsoipetch B (1989) X-Ray quantitative computed tomography: the relations to physical properties of proximal tibial trabecular bone specimens. J Biomech 22 : 837-844

13. I wano T, Kurosawa H, Tokuyama $\mathrm{H}$, Hoshikawa Y (1990) Roentgenographic and clinical findings of patellofemoral osteoarthrosis. With special reference to its relationship to femorotibial osteoarthrosis and etiologic factors. Clin Orthop 252: 190-197

14. Kiviranta I, Jurvelin J, Markku T, Samanen AM, Helminen HJ (1987) Weight bearing controls glycosaminoglycan concentration and articular cartilage thickness in knee joints of young beagle dogs. Arthritis Rheum 30:801-809

15. Kummer B (1962) Funktioneller Bau und funktionelle Anpassung des Knochens. Anat Anz 110:261-293

16. Maquet PGJ (1976) Biomechanics of the knee. Springer. Berlin Heidelberg New York

17. Mohr W (1984) Gelenkkrankheiten. Diagnostik und Pathogenese makroskopischer und histologischer Strukturveränderungen. Thieme, Stuttgart New York

18. Müller-Gerbl M, Putz R, Hodapp N, Schulte E, Wimmer B (1989) Computed tomography osteoabsorptiometry for assessing the density distribution of subchondral bone as a measure of long term mechanical adaptation in individual joints. Skeletal Radiol $18: 507-512$

19. Müller-Gerbl M, Putz R, Kenn R (1992) Demonstration of subchondral bone density patterns by three dimensional CT osteoabsorptiometry as a noninvasive method for in vivo assessment of individual long-term stress in joints. $\mathrm{J}$ Bone Min Res 7 [Suppl 2] : 411 - 418

20. Müller-Gerbl M, Putz R, Kenn R, Beyer W, Hirschfelder H, Tager KH (1992) Reaction of the subchondral bone to the changes in mechanical stress in the knee joint following osteotomy. Oral paper on the 8th meeting of the European Society of Biomechanics. June 21-24, Rome, Italy, Abstract, J Biomech (in press)

21. Outerbridge RE (1961) The etiology of chondromalacia patellae. J Bone Joint Surg [Br] 43 : 752-757

22. Pauwels F (1965) Gesammelte Abhandlungen zur funktionellen Anatomie des Bewegungsapparates. Springer, Berlin Heidelberg New York

23. Pedley RB, Meachim G (1979) Topographical variation in patellar subarticular calcified tissue density. J Anat 128 : 737-745

24. Radin EL, Abernethy PJ, Townsend PM, Rose RM (1978) The role of bone changes in the degeneration of articular cartilage in osteoarthrosis. Acta Orthop Belg 44 : 55-63

25. Radin EL, Burr DB, Caterson B, Fyhrie D, Brown TD, Boyd RD (1991) Mechanical determinants of osteoarthrosis. Semin Arthritis Rheum 21 [Suppl 2] : 12-21

26. Radin EL, Paul IL (1970) Does cartilage compliance reduce skeletal impact loads? The relative force-attenuating properties of articular cartilage, synovial fluid, periarticular soft tissues and bone. Arthritis Rheum 13:139-144

27. Radin EL, Paul IL (1971) The response of joints to impact loading. In vitro wear. Arthritis Rheum 14:521-530

28. Radin EL, Paul IL, Lowy M (1970) A comparison of the dynamic force transmitting properties of subchondral bone and articular cartilage. J Bone Joint 
Surg $|A m| 52: 444-456$

29. Radin EL, Paul IL, Rose RM (1972) Role of mechanical factors in the pathogenesis of primary osteoarthrosis. Lancet $1: 519-522$

30. Radin EL, Rose RM (1986) Role of subchondral bone in the initiation and progression of cartilage damage. Clin Orthop 213:34 - 40

31. Thompson RC, Oegema TR, Lewis JL, Wallace L (1991) Osteoarthrotic changes after acute transarticular load.
An animal model. J Bone Joint Surg [Am] $73: 990$ )-1001

32. Townsend PR. Raux P, Rose RM, Miegel RE, Radin EL (1975) The distribution and anisotropy of the stiffness of cancellous bone in the human patella. $J$ Biomech 8 : 363-367

33. Weh L, Luer C (1987) Plica medialis, Palellaform und Chondromalazie $\mathrm{Z}$. Orthopade 125: 54-62

34. Wiberg G (1941) Roentgenographic and anatomic studies on the femoropatellar joint. With special reference to chondromalacia patellae. Acta Orthop Scand 12 : 319-410

35. Wu DD, Burr DB, Boyd RD, Radin EL (1990) Bone and cartilage changes following experimental varus or valgus tibial angulation. J Orthop Res 8 : 572 585

Received December 21, 1992 / Accepled in final form April 30, 1993 